\title{
Respon Pengunjung dan Pedagang Terhadap Kondisi Lingkungan Termal (Suhu Udara) Di Pasar Wolowona Kota Ende
}

\author{
*Petrus Jhon Alfred Depa Dede ${ }^{1}$ \\ ${ }^{1}$ Program Studi Arsitektur Fakultas Teknik Universitas Flores, Ende \\ *) Correspondence e-mail: ff3redo@gmail.com
}

\begin{abstract}
ABSTRAK
Pasar Wolowona merupakan salah satu pasar yang ada di Kota Ende yang menyediakan kebutuhan pokok masyarakat dengan aneka jenis jualan. Aktifitas jual beli di pasar ini sangat itens. Kenyamanan lingkungan (suhu udara) di pasar di saat terjadinya aktifitas jual beli merupakan salah satu faktor penting yang dapat mempengaruhi hasil penjualan dan daya tarik pembeli. Penelitian ini bertujuan untuk mencari tahu tentang bagaimana respon dari para pengunjung dan penjual terhadap kondisi suhu udara di pasar Wolowona sebagai bagian dari kenyamanan termal dalam desain arsitektur. Penelitian dilakukan dengan metode kualitatif diskriptif. Dalam penelitian ini pengumpulan data dilakukan dengan survey, observasi dan studi literatur. Jumlah responden yang di wawancara adalah 30 orang, terdiri dari 13 orang pedagang, 13 orang pengunjung dan 4 orang petugas, yang berusia 15 - 60 tahun. Waktu wawancara dilakukan pada pagi, siang dan sore hari yaitu pada pukul 09:00, pukul 13:00 dan pukul 17:00. Kuesioner respon diambil menggunakan indeks PMV (Predicted Mean Vote) dengan 7 poin skala sensasi termal, yaitu -3 (Dingin), -2 (Sejuk), -1 (Agak sejuk), 0 (Netral), 1 (Agak hangat), 2 (Hangat), dan 3 (Panas). Hasil penelitian menunjukkan, bahwa para pengunjung dan penjual merasa tidak pus dengan kondisi kenyamanan (suhu udara) yang ada. Data dari 30 orang responden yang di wawancara hanya 5 orang responden yang merasakan nyaman/ netral dan 12 orang merasakan hangat serta 13 orang lainya merasakan panas. Oleh karena itu diperlukan tindakan dengan menata kembali lingkungan dan desain pasar.
\end{abstract}

Kata Kunci : Pasar, Pedagang, Pengunjung, Suhu Udara

\section{PENDAHULUAN}

Pasar adalah salah satu dari berbagai sistem, institusi, prosedur, hubungan sosial dan infrastruktur dimana usaha menjual barang, jasa dan tenaga kerja untuk orang-orang dengan imbalan uang. Satu kegiatan yang berlangsung di pasar merupakan suatu kegiatan perekonomian yaitu barang dan jasa yang dijual menggunakan alat pembayaran. Menurut Wikipedia Indonesia (2008), Pasar Tradisional merupakan tempat bertemunya penjual dan pembeli serta ditandai dengan adanya transaksi penjual dan pembeli secara langsung, bangunan biasanya terdiri dari kios - kios gerai, los dan dasaran terbuka yang dibuka oleh penjual maupun suatu pengelolah pasar, kebanyakan menjual kebutuhan hidup sehari - hari seperti bahan - bahan makanan seperti ikan, buah, sayur - sayuran, telur, daging, kain, pakaian, barang elektronik, jasa dan lain - lain.

Pasar Wolowona adalah salah satu Pasar Tradisional yang ada di Kota Ende. Pasar Wolowona ini menjual berbagai bahan kebutuhan pokok, sandang, pangan dan papan. Pasar Wolowona merupakan pasar harian yang kegiatan jual belinya dilakukan tiap hari dengan jadwal operasional pukul 06.00-18.00. Namun saat ini pasar Wolowona masih dalam kondisi yang kurang layak jika dikaji dari segi kenyamanan. Kenyamanan lingkungan pasar pada saat terjadinya aktivitas jual beli merupakan faktor penting yang dapat mempengaruhi hasil penjualan dan daya tarik dari tempat tersebut. Menurut Rilatupa (2008), Kenyamanan adalah bagian dari salah satu sasaran karya Arsitektur. Kenyamanan terdiri atas kenyamanan psikis dan kenyamanan fisik. Kenyamanan psikis yaitu kenyamanan kejiwaan (rasa aman, tenang, gembira, dan lain-lain) yang terukur secara subjektif (kualitatif). Sedangkan kenyamanan fisik dapat terukur secara objektif (kuantitatif), yang meliputi kenyamanan spasial, visual, auditorial dan 
termal. Kenyamanan termal merupakan salah satu usur kenyamanan yang sangat penting, karena menyangkut kondisi suhu ruangan yang nyaman.

Tujuan dari penelitian ini adalah untuk mengetahui respon dari pengunjung, pedagang dan petugas pasar terhadap kondisi lingkungan termal (suhu udara) di pasar Wolowona. Sehingga hasil yang diharapkan adalah dapat memberikan gambaran umum tentang kondisi lingkungan termal (suhu udara) di Pasar Wolowona yang diwakilkan oleh para responden.

\section{Kenyamanan Termal}

Kenyamanan berarti kondisi nyaman/perasaan nyaman, yang memiliki pengertian yaitu suatu kondisi pikiran yang mengekpresikan kepuasan terhadap lingkungannya atau dimana tubuh merasakan kedaan yang lebih baik daripada keadaan fisik lingkungannya (Fanger, 1970). Menurut Szokolay (1980) kenyamanan termal adalah kondisi yang mengekspresikan tingkat kepuasan seseorang terhadap lingkungan termalnya. Rasa kepuasan dari seseorang terhadap lingkungannya karena dipengaruhi oleh iklim (radiasi matahari, suhu udara, kelembaban udara, dan kecepatan angin) dan individu (pakaian, usia dan jenis kelamin).

Daerah nyaman fisik manusia, untuk tipe udara diam, dapat dicapai pada kondisi bersuhu 21-27oC dan berkelembaban 20-70\%. Selain itu, untuk tipe udara yang bergerak (kecepatan 0,1-1,0 m/dt), daerah nyaman dapat dicapai pada kondisi bersuhu 25-35oC dan berkelembaban 5-85\%. Sebaliknya, kondisi ruang bangunan mempunyai status di luar toleransi kenyamanan termal jika mempunyai keadaan udara yang bersuhu di atas $510 \mathrm{C}$ dan keadaan angin yang berkecepatan lebih dari $2 \mathrm{~m} / \mathrm{dt}$.

\section{Respon Tubuh terhadap Kondisi Termal}

Tubuh manusia melepaskan panas secara terus menerus sesuai dengan kondisi lingkungan dan pakaian yang di pakainya, tetapi juga dapat menghasilkan panas sebanding dengan makanan dan tingkat kegiatan tubuhnya. Tubuh manusia akan kedinginan bila terlalu cepat kehilangan panas, dan merasa kepanasan bila tidak bisa melepas panas dalam waktu yang tepat. Apabila suhu udara di daerah sekitar tubuh manusia lebih tinggi dari suhu nyaman yang diperlukan, maka aliran darah pada permukaan tubuh akan meningkat dan terjadi peningkatkan suhu kulit. Peningkatan suhu ini bertujuan untuk melepaskan panas secara radiasi dari dalam tubuh ke udara di sekitarnya. Proses pengeluaran keringat akan terjadi pada suhu udara yang lebih tinggi, sebagai tindak lanjut dari usaha pelepasan panas tubuh melalui proses penguapan (Karyono, 2001).

Pada situasi dimana suhu udara lebih rendah dari yang diperlukan tubuh, peredaran darah ke permukaan tubuh akan dikurangi untuk mengurangi pelepasan panas ke udara disekitarnya. Pada situasi ini tangan atau kaki menjadi dingin dan pucat. Otot-otot akan berkontraksi dan tubuh akan menggigil pada suhu udara yang lebih rendah, ini merupakan usaha tubuh untuk dapat memperoleh tambahan panas melalui peningkatan proses metabolisme. Pada kondisi lebih ekstrim, baik terlalu panas ataupun terlalu dingin, manusia mungkin tidak lagi mampu bertahan untuk hidup (Szokolay, 1980).

Tubuh manusia mempunyai kemampuan dalam mengatur keseimbangan suhu tubuh dengan berbagai cara. Suhu tubuh manusia memerlukan suhu tetap dan harus dipertahankan sekitar $37^{\circ} \mathrm{C}$, sedangkan untuk suhu kulit dapat bervariasi antara 31 dan $34^{\circ} \mathrm{C}$. Daerah suhu inilah yang kemudian disebut dengan suhu netral atau nyaman. Dalam kondisi yang nyaman ini terdapat daerah suhu dimana manusia tidak memerlukan usaha apapun, seperti halnya menggigil/ tidak merasakan dingin atau mengeluarkan keringat/ tidak merasakan panas (Karyono, 2001). Suhu netral dapat terjadi bila seseorang telah terbiasa sebagai hasil dari proses aklimatisasi fisiologi dan kebiasaan yang berhubungan dengan kondisi lingkungan termalnya (Szokolay, 1980).

Szokolay (1980) menjelaskan bahwa setiap individu dapat mengkontrol tingkat pertukaran panas antara permukaan tubuh dan lingkungannya dengan cara memilih pakaiannya. Untuk iklim dingin, jenis pakaian yang digunakan adalah pakaian katun, jas dan rompi dengan indikasi nilai 1.0-3.0 clo $(1.0$ clo $=0.15 \mathrm{~m} 2$ 
$\mathrm{K} / \mathrm{W})$ Bekerja dan melakukan aktivitas juga mempengaruhi besar kecilnya panas yang timbul dari dalam tubuh. Semakin giat manusia bekerja dan melakukan aktivitas maka semakin besar suhu panas yang dilepaskan tubuh ke udara, sehingga dapat menghasilkan kenaikan suhu tubuh dan menghangatkan tubuh. Panas yang dihasilkan ketika tubuh melakukan pekerjaan secara sadar 1.0-3.0 met (1 met/metabolic rate $\left.=58 \mathrm{~W} / \mathrm{m}^{2}\right)$, (Frick \& Suskiyatno, 2007).

\section{Pasar Wolowona}

Pasar Wolowona terletak di sebelah Timur Kota Ende tepatnya di Kelurahan Rewarangga Selatan, Kecamatan Ende Timur. Batas-batas lokasi sebagai berikut, Sebelah Utara: perkantoran dan perumahan penduduk, Selatan: jalan menuju Ndona, Barat: jalan menuju Maumere, Timur: Sungai Wolowona. Pasar Wolowona mempunyai Luas Lahan $7581 \mathrm{~m}^{2}$ atau $0,75 \mathrm{Ha}$. Di pasar Wolowona ada beberapa bangunan utama yang diperuntukan bagi para pedagang, namun karena melonjaknya jumlah pedagang dan kurangnya kapasitas bangunan membuat pedagang akhirnya membuka lapak jualan di sekitaran pasar, bahkan sampai pada trotoar.

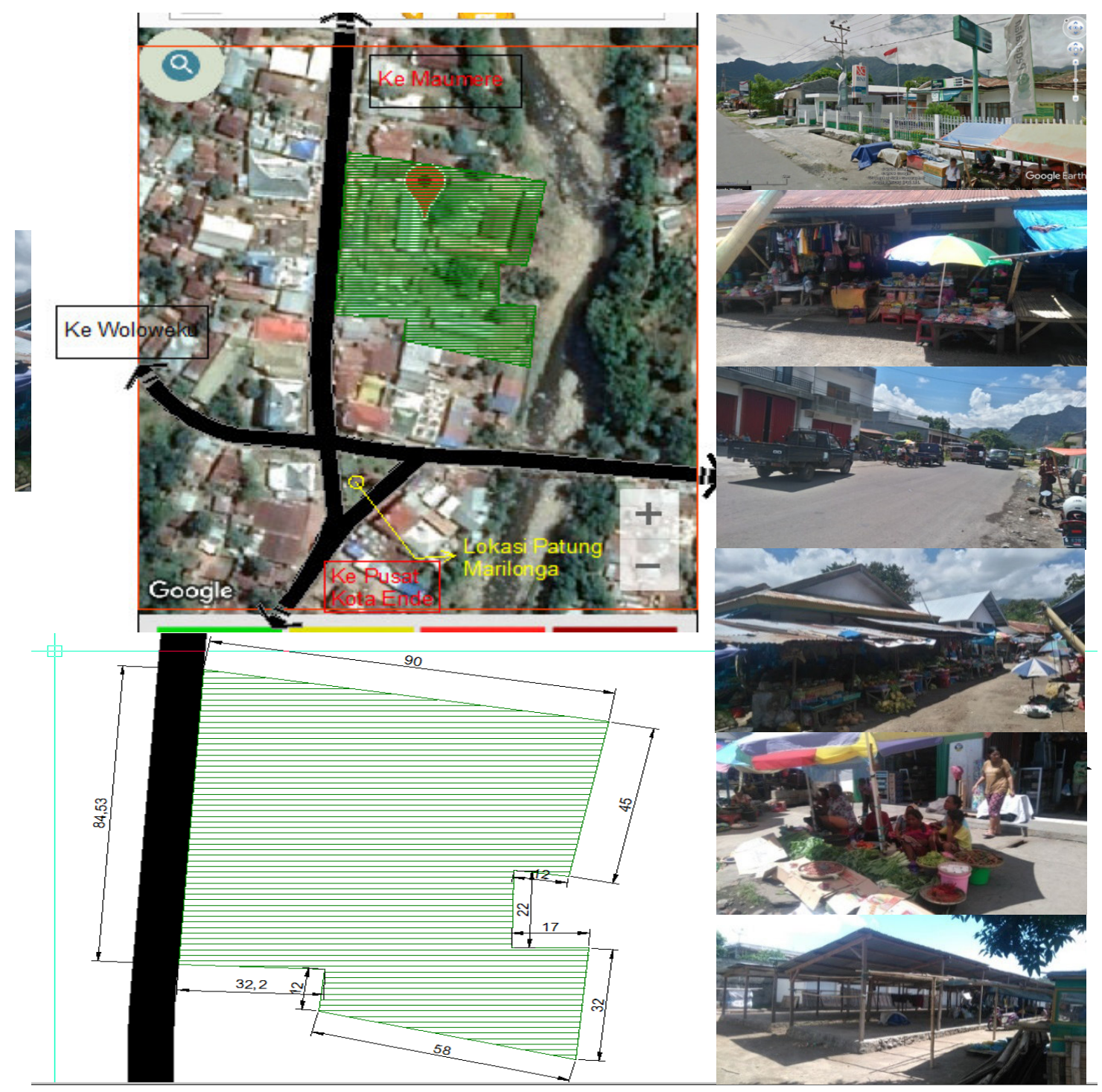

Gambar 1. Lokasi Pasar Wolowona

\section{METODE}


Metode penelitian dilakukan dengan model kualitatif diskriptif. Dalam penelitian ini pengumpulan data dilakukan dengan survey, observasi dan studi literatur. Survey dilaksanakan dengan pengamatan sederhana yang dibantu dengan alat bantu berupa kamera. Observasi dilakukan dengan pengamatan lebih lanjut untuk memfokuskan permasalahan penelitian, seperti wawancara kepada subyek yang berada di wilayah obyek penelitian. Dan studi literatur dilakukan dengan pencarian sumber-sumber pustaka yang berasal dari buku-buku studi ilmiah, arsip koran dan majalah.

\section{Responden}

Responden yang diambil adalah yang berusia 15 - 60 tahun. Jumlah responden yang di wawancara adalah 30 orang, terdiri dari 13 orang pedagang, 13 orang pengunjung dan 4 orang petugas, dengan sistem random/ acak untuk menjawab kuesioner yang dibagikan. Wawancara dilakukan pada tiga periode waktu yaitu: pagi, siang dan sore. Tiga periode waktu diambil pada pukul 09:00, pukul 13:00 dan pukul 17:00.

\section{Kuesioner}

Kuesioner respon kondisi termal terdiri dari dua bagian pertanyaan yaitu, pertama adalah kenyamanan yang ditinjau dari faktor waktu, kedua kenyamanan yang ditinjau dari faktor kebiasaan. Skala kesan termal yang diambil berdasarkan indeks yang diperkenalkan oleh Fanger (1970) yakni PMV (Predicted Mean Vote). PMV merupakan sebuah indeks yang memperkirakan nilai rata-rata vote kelompok besar manusia pada 7 poin skala sensasi termal, yaitu -3 (Dingin), -2 (Sejuk), -1 (Agak sejuk), 0 (Netral), 1 (Agak hangat), 2 (Hangat), dan 3 (Panas).

\section{HASIL DAN PEMBAHASAN}

Kota Ende tergolong dalam iklim tropis karena musim hujan umumnya antara November sampai Maret sedangkan musim kemarau lebih panjang yaitu antara April sampai Oktober. Curah hujan tertinggi antara Desember dan Januari. Pada bulan Juni dan Juli malam hari akan sangat dingin dan puncak kemarau pada bulan Agustus dan Oktober.

\section{Karakteristik Pasar Wolowona}

Keadaan diluar pasar: kondisi jalan pada saat tertentu macet sehingga menyulitkan penumpang untuk mengakses ke pasar, dan hanya dapat diakses dari depan. Hampir seluruh lahan digunakan untuk bangunan sehingga tidak memiliki tempat parkir. Saat ini jalanan di gunakan sebagai tempat parkir sehingga membuat kemacetan lalu lintas. Bahkan di pasar Wolowona tidak memiliki ruang terbuka/ lahan hijau di sekitar bangunan, sehingga tidak dapat meredam suhu udara yang panas.

Keadaan didalam pasar: kondisi koridor atau lorong di dalam bangunan yang sempit sehingga ruang gerak menjadi sempit. Hal ini menyebakan kondisi sangat panas karena sirkulasi udara tidak nyaman dan tidak teratur. Lapak-lapak pedagang di desain tanpa memperhatikan pergerakan dan aliran udara, radiasi panas matahari langsung di serap ke bangunan karena tidak adanya pembayangan yang dapat meneduhkan bangunan.

\section{Respon Terhadap Kondisi Termal (Suhu Udara)}

\section{Respon Pengguna}

Dari hasil pengamatan dan wawancara respon dari para pengunjung, pedagang dan petugas yang sedang malakukan aktifitas/ kegiatan di pasar terhadap gejala suhu yang panas, adalah sebagai berikut:

1. Mereka tidak mampu untuk berkonsentrasi dengan baik ketika sedang malakukan aktifitas/ kegiatan di pasar.

2. Kondisi tubuh sering mengalami kram otot, panas ruam pada kulit, dan merasa sangat haus.

3. Sering merasa kelelahan, pusing, mual, sakit kepala, dan kulit terasa lembab. 
4. Kadang-kadang juga kulit terasa kering dan panas.

Dari gejala-gejala yang terjadi di atas dapat mengakibatkan:

1. Pembeli kurang memperhatikan dengan baik ataupun memilih-milih secara benar/ baik kualitas barang yang dibelinya karena kurangnya kosentrasi.

2. Kurang memperhatikan terhadap sesuatu yang ada disekitarnya sehingga tidak peduli/ merespon segala tindakan/ hal yang terjadi.

3. Tidak memperhatikan, kurang waspada terhadap barang yang dibawa/dibeli sehingga sering terjadi kehilangan, tertinggal, tercecer/ jatuh tanpa disadarinya.

4. Tingkat emosional tinggi, sehingga sering mengeluh, marah, protes bahkan terjadi pertengkaran.

\section{Adaptasi Pengguna}

Dalam mengatasi dan menyesuaikan diri dengan suhu yang panas (tekanan lingkungan), tingkah laku (adaptasi) para pengunjung, pedagang dan petugas dalam malakukan aktifitas/ kegiatan di pasar, adalah sebagai berikut:

1. Pengunjung

Panas terjadi pada siang hari antara pukul 11.00-15.00, para pengunjung menyesuaikan diri dengan membawa penutup kepala, meminum air dingin, dan berkipas-kipas. Kadang-kadang pengunjung juga mencari tempat duduk/ berdiri di tempat yang teduh atau tempat yang lebih sejuk. Ada juga beradaptasi dengan memakai pakain dan dandanan yang simpel seperti bercelana pendek, berkaos oblong dan bersandal.

2. Pedagang dan petugas

Seiring waktu berjalan para pedagang/ penjual dan petugas menyesuaikan diri (beradaptasi) terhadap kondisi panas yang terjadi di dalam pasar yaitu dengan merubah tingkah laku mereka, misalnya dengan melepaskan baju/ memakai pakain yang tidak menyerap panas, sering meminum air dingin, berkipaskipas, dan/ atau mengurangi beban kerja mereka (menutup lapak sebelum berakhir jam operasi pasar).

3. Skala Kesan Termal

Skala kesan termal yang didapat dari responden (pengunjung, pedagang dan petugas pasar) adalah panas, hangat, dan nyaman/ netral. Jumlah responden yang merasakan sensasi nyaman/netral (skala 0) sebanyak $15 \%$, dengan jumlah responden sebanyak 5 orang. Jumlah responden yang merasakan sensasi hangat (skala 2) sebanyak $40 \%$ dari jumlah responden, dengan jumlah responden yang merasakan sensasi hangat sebanyak 12 orang. Jumlah responden yang merasakan panas (skala 3 ) sebanyak 45\%. Jumlah responden yang merasakan sensasi panas sebanyak 13 orang.

Pada umumnya yang merasakan sensasi nyaman/netral, sebagian besar dirasakan pada pagi hari (pukul 07:00-09:00) dan sore hari (di atas pukul 16:00), sensasi hangat sebagian besar terjadi pada pagi hari (di atas pukul 09:00-10.00) dan sensasi panas terjadi pada siang hari pukul 11.00-15.00.

Tabel 1. Sensasi termal

\begin{tabular}{ccc}
\hline Sensasi Termal & Responden & Prosentase $(\%)$ \\
\hline Nyaman & 5 Orang & $15 \%$ \\
Hangat & 12 Orang & $40 \%$ \\
Panas & 13 Orang & $45 \%$ \\
\hline Jumlah & 30 Orang & $100 \%$ \\
\hline
\end{tabular}

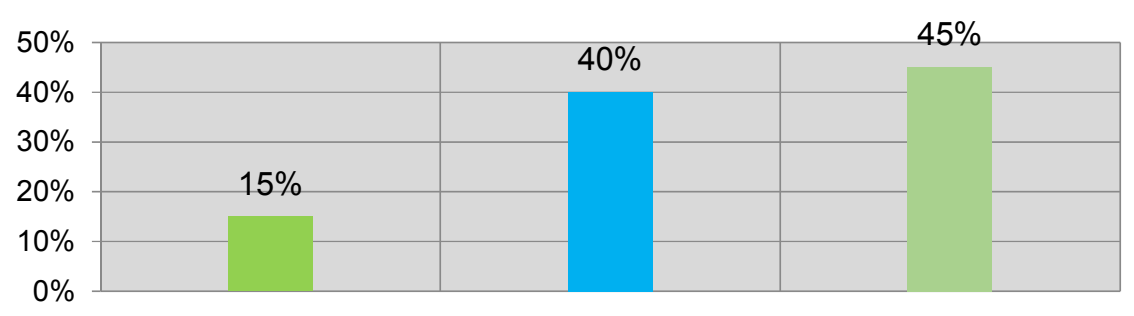

Gambar 2. Prosentase sensasi termal 


\section{KESIMPULAN}

Pasar Wolowona sendiri hadir sebagai salah satu pasar yang ada di Kota Ende dan turut serta membantu roda perekonomian masyarakat kota Ende dan sekitarnya, menyediakan kebutuhan pokok masyarakat dengan aneka jenis jualan. Namun saat ini ditemukan bahwa kondisi lingkungan termal (suhu udara) pada pasar Wolowona sendiri kurang begitu nyaman bagi pengguna pasar seperti para pengunjung, pedagang dan petugas pasar yang melakukan kegiatan/ aktifitasnya diluar dan didalam pasar. Dari uraian di atas dapat ditarik kesimpulan sebagai berikut:

1. Dari jumlah responden yang di wawancara sebanyak 30 orang, hanya 5 orang responden yang merasakan sensasi nyaman/ netral. Sebanyak 12 orang merasakan sensasi hangat dan yang merasakan sensasi panas sebanyak 13 orang.

2. Sensasi nyaman/ netral dirasakan pada pagi hari yaitu pukul 07:00 sampai dengan pukul 09:00 dan pada sore hari di atas pukul 16:00. Yang merasakan sensasi hangat terjadi pada pagi hari di atas pukul 09:00 sampai dengan pukul 10.00 dan sensasi panas terjadi pada siang hari pukul 11.00 sampai dengan pukul 15.00.

3. Durasi nyaman dirasakan berlangsung selama 2 jam, sedangkan untuk sensasi hangat durasinya hanya selama 1 jam (durasi terpendek). Dan sensasi panas mengalami durasi terpanjang yaitu selama 4 jam.

4. Kondisi lingkungan pasar tidak mendukung sehingga menyebabkan ketidak nyamanan (menimbulkan suhu udara yang panas) seperti tidak memiliki ruang terbuka/ lahan hijau di sekitar bangunan, koridor atau lorong di dalam bangunan yang sempit, lapak-lapak pedagang di desain tanpa memperhatikan pergerakan dan aliran udara, serta radiasi panas matahari langsung di serap ke bangunan.

\section{DAFTAR PUSTAKA}

Fanger, P.O. (1970). Thermal Comfort: Analysis And Applications In Environmental Engineering, McGraw-Hill, New York.

Frick, Heinz \& Suskiyatno, Bambang. (2007). Dasar-dasar Arsitektur Ekologis: Sari Eko-Arsitektur 1, Penerbit Kanisius \& ITB.

Karyono, Tri Harso. (2001). Penelitian Kenyamanan Termis Di Jakarta Sebagai Acuan Suhu Nyaman Manusia Indonesia, Jurnal Dimensi Teknik Arsitektur Vo.29 No.1

Szokolay, S.V. (1980). Environmental Scince Handbook For Architecs And Builders, The Construction Press, Lancaster. 